2020, Volume 14, International Conference Innovative Business Management \& Global Entrepreneurship (IBMAGE 2020), pages: 744-757 |

https://doi.org/10.18662/lumproc/ibmage2020/55

\section{Analysis and Evolution of Profitability in the Pharmaceutical Field in Romania}

\section{Izabela Diana HADA ${ }^{1}$}

1 Ph.D. Student, „1 Decembrie 1918” University of Alba Iulia, România, e-mail: izabelahada@yahoo.com
Abstract: The pharmaceutical industry is an important field of activity that contributes to the diagnosis, treatment, maintenance of the health of the population. The need of pharmaceuticals has led to an increase in both the number of drug manufacturers and the number of distributors. A significant part of the specialized studies deals with the problem of the profitability of the pharmaceutical industry. The study of the financial performance of the economic entities in the pharmaceutical field in Romania is a necessary concern in the conditions of a progressive annual increase of the profitability of this sector. The main purpose of this paper is the analysis and presentation of the evolution of profitability indicators (return on assets, return on capital, return on sales) as part of the activity of assessing the financial performance of economic entities operating in Romania in the pharmaceutical industry (manufacturing of basic pharmaceutical products - CAEN code 2110). Profitability indicators were analyzed for a number of 46 entities in the pharmaceutical industry in Romania for a period of 20 years (1999-2018). We are talking in this case about a turnover of 1.1 Billion lei $(249.2$ million euros), a number of employees of 3,098 employees, a profit of 135.2 million lei (30.7 million euros) - representing $0.12 \%$ of the net profit made in Romania. The research results show that in the period 2008-2009, the financial crisis left a strong mark on the evolution of profitability in the pharmaceutical industry. However, during the 20 years we talk about a positive evolution, in the sense of increasing the profitability of this field, which justifies the increase in the consumption of pharmaceuticals products.

Keywords: financial performance; $\mathrm{ROA}$; ROE; return on sales (ROS); pharmacentical field.

How to cite: Hada, I.D. (2020). Analysis and Evolution of Profitability in the Pharmaceutical Field in Romania. In M. W. Staniewski, V. Vasile, \& A. Grigorescu (vol. ed.), Lumen Proceedings: Vol. 14. International Conference Innovative Business Management \& Global Entrepreneurship (IBMAGE 2020) (pp. 744-757). Iasi, Romania: LUMEN Publishing House. https://doi.org/10.18662/lumproc/ibmage2020/55 


\section{Introduction}

The pharmaceutical industry represents an important activity field that contributes to the diagnosis, treatment, maintenance of the health of the population. The need for pharmaceuticals translates into an increase first in the number of drug manufacturers and then in the number of drug distributors. In 2010, the added value of companies in the pharmaceutical sector, at world wealth, represented $0.80 \%$ of GDP (gross domestic product), contributing directly by $0.32 \%$, and indirectly by $0.48 \%$ ), but the most important is the fact that innovative pharmaceutical companies had the largest share in the global contribution of GDP (60\%) [15]. The increase in turnover in the pharmaceutical industry, which reached $26 \%$ in the period 2012-2017, leading to a significant evolution of profitability, which translates into the development of large pharmacy range as well as the aggressive promotion of pharmaceuticals [6].

A study of the financial performance of the economic entities in the pharmaceutical field in Romania is a necessary concern in the conditions of a progressive annual increase of the profitability of this sector. In this sense, the research aim is analysis and presentation of the evolution of profitability indicators (return on capital-ROE, return on assets-ROA, return on salesROS) as part of the activity of assessing the financial performance of economic entities operating in Romania in the pharmaceutical industry (manufacturing of basic pharmaceutical products - CAEN code 2110). Profitability indicators were analyzed for a number of 46 entities in the pharmaceutical industry in Romania for a period of 20 years (1999-2018). We are talking in this case about a turnover of 1.1 Billion lei (249.2 million euros), a number of employees of 3,098 employees, a profit of 135.2 million lei (30.7 million euros) - representing $0.12 \%$ of the net profit made in Romania. The research results show that in the period 2008-2009, the financial crisis left a strong mark on the evolution of profitability in the pharmaceutical industry. However, during the 20 years we talk about a positive evolution, in the sense of increasing the profitability of this field, which justifies the increase in the consumption of pharmaceuticals products.

\section{Problem Statement}

One of the most profitable branches of the global industry is the pharmaceutical industry, and pharmaceuticals that take the form of drugs have become absolutely necessary for society, contributing to human development by preventing, detecting and treating various diseases and improving quality of life [21]. 
The issue of the profitability of the pharmaceutical sector is studied by authors such as Leahy [16], who examines the profitability determinants of pharmaceutical companies in US. Statistics shown that the pharmaceutical industry is one of the most competitive and dynamic in the sectors of activity on the market, which is why competition is very close. Barriers to entry in this market, as well as research and development costs are relatively high, so that they use mergers and acquisitions, mainly in the innovative area of industry, thus generating one of the most active economic segments, after the banking sector [20]. In a study, Mikulic M. [17] says that the pharmaceutical industry has the highest percentage of spending on research and development compared to other industries, and the United States is at the top of the rankings as a traditional stone of pharmaceutical innovation (the origin of most new substances marketed can be tracked in the United States).

Profitability is the most important part of financial performance. Studies in the field deal with the direct link between performance and profitability. Researchers Deng \& al [10] mentions that the financial performance has four major components: the stage of development, liquidity, ability to make a profit, and solvency. Entity's performance is closely linked to the way managers manage its activity, the way they procure their resources and the way they spend them to make a profit [23]. According to author Yvon Pesqueux quoted by Issor [14], performance can be considered a "strange attraction" in its ability to absorb multiple translations: economic (competitiveness), financial (profitability), legal (solvency), organizational (efficiency) or even social. Since the easiest way to reflect the performance of an asset is through its results, expressed either in absolute terms (profit) or in relative terms (profitability), we can say that based on the profit and loss account the performance of the company is analyzed, calculating, in this sense, various indicators [19]. Financial statements are a necessary basis for measuring a company's financial position and performance [2].

A thorough research of the issue of measuring financial performance shows more and more studies that present the indicators of profitability as the main pillar of measuring financial performance. Analysis of profitability rates (which measures the company's ability to generate profits and investments) is important for all the users of financial statements [18]. A study published by Căruntu [8] states that macroeconomic efficiency translates into profitability, in other words, the results obtained in relation to the efforts (or expenditures) with the factors of production. The same bibliographic source mentions that the activity of characterizing the economic performance supposes the determination of the return rates 
information, which must be relevant, reliable and comparable. In a study published by Nishanthini A. and Nimalathasan B [14] we find the concept that profitability and profit are different indicators, profitability (composed of two words profit and capacity) being an indicator of earning capacity, defined as the property of investment to generate profit from its use. In a modern market economy, maximizing profitability is the fundamental criterion of firms' decisions to employ the costs of organizing production, expanding or restricting it. It should be noted that economic efficiency has a much wider scope than the notion of profitability, as it covers the entire system of indicators that reflect the various specific forms of economic efficiency - a system grouped into subsystems including the subsystem of profitability indicators. However, profitability mirrors the final economic efficiency of the entire economic and financial activity, constituting a true quintessence of all aspects of economic efficiency [12].

Expression of economic efficiency with edifying synthesis power, profitability includes economic and financial aspects of entity activities representing an indicator of reference for substantiating decisions and guiding their behavior, an essential economic performance component, being the basic goal of economic activity and the first condition for their survival and development on the competitive economic trade [3]. In assessing and measuring financial performance, rates of return are among the most used methods, providing the opportunity to identify the factors that have influenced the dynamics of performance [1]. Profitability rates are the basic indicators for characterizing the company's performance, and addressing the issue of profitability involved the correct placement of the entity in the strategic field [7].

Approaches related to the indicators used in the activity of assessing financial performance are also found in the authors Yaling Deng, Shuliang Zou, Daming You [10], who in their paper also make a brief foray into the indicators used by other researchers, so that some of them considers that the evaluation of the company's performance is a decision-making issue that has been a topic of scientific research, starting with some authors who used the return on assets, the return on capital and the net profit margin to evaluate the financial performance of a number of 19 companies, others who used ROA and finding that social responsibility has an important impact on financial performance, and last but not least other authors who have researched the relationship between performance and environmental management using mainly two indicators: return on capital and earnings per share (EPS). The rate of return on assets (ROA) measures the overall efficiency of management in generating profits based on assets and the return on capital employed (ROCE) is a report that indicates the efficiency 
and return on capital investments of a firm [22]. The return on capital employed is a significant indicator for evaluating the entity performance, whose objective is to assess the extent to which investments made by shareholders have resulted in increased profit [5].

In a recent study published by CECCAR (2020) [9] we find the importance of financial profitability (ROE), so that an indicator of performance pursued with interest of management and capital holders is represented by the return on equity (the financial rate of profitability). Through its analysis, investors assess the extent to which the investment made can be considered profitable or not.

Some authors emphasize the importance of profitability indicators in determining the path of an economic entity. Information on a company's performance, is important for evaluating changes in financial resources that the company control it in the future and for prescribe the ability to make cash flows with existing resources, and based on performance formulates reasoning regarding the efficiency with which the enterprise can use new resources [3]. The determination of profitability indicators has a special significance in the activity of industrial financial analysis [11].

Presenting the most current concepts regarding the notion of performance (typology, importance, measurement indicators), Hada I.D. [13] aimed to highlight the importance of knowing and measuring it, based on an empirical study conducted on a sample of five best performing companies in the pharmaceutical field (companies whose object of activity consists in the retail sale of pharmaceutical products in specialized stores - CAEN 4773) for which profitability indicators (ROA, ROE, NPM) were analyzed over a period of fifteen years, 2004-2018.

\section{Research Questions/Aims of the research}

In an economic environment in a continuous change, the profitability of the pharmaceutical sector in Romania represents a significant research concern. In this sense, the main research aim is to analyze and describe the profitability evolution of the pharmaceutical sector in Romania for the last 20 years (1999-2018). Starting from the main objective pursued, the following specific research objectives were established: presentation of significant concepts related to financial performance evaluation, use of profitability indicators in the activity of measuring financial performance, definition and characterization of return on assets, capital and sales profitability, highlighting the research interests regarding the study of the pharmaceutical sector, as well as the analysis of profitability rates for economic entities in the field of manufacturing of basic pharmaceutical 
products. In order to achieve the proposed objectives, we conducted a study on a number of 46 entities in the pharmaceutical industry, over a period of 20 years (1999-2018). The entities used as the basis of the study represent, according to topfirme.com [24], all the entities whose object of activity is the producer of basic pharmaceuticals. In the sense of the proposed objectives, the following research hypotheses were formulated: the most important indicators for measuring financial performance are profitability indicators (ROA; ROE; ROS), the activity of measuring financial performance is of major importance for decision makers, consumption growth and of the sale of pharmaceutical products also justifies the increase of the profitability of this sector in Romania in the last 20 years. The research is divided in two important parts: first is dedicated to the presentation of the most relevant studies in the field of profitability of the pharmaceutical sector and the second part, respectively the results section includes the study and analysis of profitability indicators in the Romanian pharmaceutical industry.

\section{Research Methods}

Aiming to analyze and present the evolution of profitability indicators for the Romanian pharmaceutical sector, the research aims to present the most important aspects related to the appreciation of profitability as part of the activity of measuring financial performance, channeled on the Romanian pharmaceutical sector, using specialized bibliographic references as part of review of the specialized literature. The exposition of the significant concepts in relation to the research topic was possible by using as a research method the theoretical documentation and the documentary analysis. The study of the synthesis documents was necessary as a basis for the research regarding the determination of the profitability indicators relied on information contained in the financial statements of all the 46 economic entities. To achieve the main objective of the paper we used as methods: operational research, empirical study, graphic representation. The base of research is represented by 46 economic entities in the pharmaceutical field (more precisely, companies whose goal of activity consists in manufacture of basic pharmaceuticals) for which the profitability indicators (ROA; ROE; ROS) were analyzed over a period of 20 for years (1999-2018). The indicators were calculated started from the information contained in the financial statements of analyzed entities, published on the mfinante.ro website [25]. For each year we determined the turnover, the gross / net profit, the own capitals, the total assets by summing up these indicators for each analyzed entity. Based on the total, we calculated the profitability indicators and subsequently represented graphically the 
evolution in their dynamics. Finally, as a research method we used participatory observation for the interpretation of research results and, substantiating of opinions based on the results obtained.

\section{Findings}

The economic return known in the literature as return on assets (ROA) means the ability to make profit as a consequence of efficient use of stocks and successful management and is used as a significant indicator in assessing financial performance [4]. The rate of economic profitability express the link during an economic output and the economic capital employed to obtain it, being independent of the financial structure (degree of indebtedness), fiscal policy of profit taxation, as well as exceptional elements [12].

The financial return identified in the researches as return on equity (ROE) represent an important indicator for evaluating the entity performance. The financial return of profitability is a basic indicator that defines the performance of enterprises that is directly affected by commercial profitability, the efficiency of economic profitability, but also the financial policy of the enterprise [7]. The commercial return known in the literature as the return on sales (ROS) is calculated as a ratio between gross result and turnover.

To achieve the main objective pursued, we analyzed the profitability indicators for a number of 46 entities in the pharmaceutical industry in Romania for a period of 20 years (1999-2018). For the beginning, we performed a descriptive statistical analysis of the two performance indicators, respectively the net profit and the turnover. Based on the processing of the net profit and the turnover of each pharmaceutical entity, we achieved the following results:

Table 1: Descriptive statistics of net profit for entities in pharmaceutical fields in Romania in the period 1999-2018

\begin{tabular}{lrrrrrrrrrr}
\hline \multicolumn{2}{l}{ Year Mean } & Standard Error & Median & Standard Deviation & Kurtosis & Skewness & Minimum & Maximum Sum & Surl \\
\hline 1999 & 298458,29 & 222460,79 & 9988 & 917229,35 & 11,13 & 3,24 & -350219 & 3561144 & 5073791 \\
2000 & 407278,79 & 323065,59 & 12915 & 1408210,27 & 5,06 & 1,94 & -1964908 & 4728708 & 7738297 \\
2001 & 937623,95 & 530282,05 & 6203 & 2430057,65 & 5,07 & 2,33 & -1672529 & 8664956 & 19690103 \\
2002 & 883814,14 & 577389,87 & 26253 & 2645932,80 & 13,08 & 3,44 & -1211362 & 11327808 & 18560097 \\
2003 & 1143697,35 & 694364,52 & 20587 & 3105292,55 & 7,52 & 2,75 & -784044 & 11863805 & 22873947 \\
2004 & 1020382,74 & 629139,58 & 40750 & 3017247,45 & 10,06 & 3,15 & -682772 & 12424687 & 23468803 \\
2005 & 1203828,64 & 1296862,16 & 21609 & 6484310,80 & 7,09 & 2,08 & -12953219 & 22086624 & 30095716
\end{tabular}


Lumen Proceedings 14 | International Conference IBMAGE 2020

\begin{tabular}{rrrrrrrrrr}
2006 & 2107444,50 & 1204997,93 & 35263 & 6144307,95 & 7,93 & 2,95 & -1086295 & 23839146 & 54793557 \\
2007 & 1264733,26 & 1650393,19 & 22973 & 8575694,55 & 8,78 & 1,48 & -22431120 & 32456007 & 34147798 \\
2008 & $-301580,25$ & 1248643,51 & 11445 & 6607200,42 & 19,52 & $-3,86$ & -31305737 & 10572756 & -8444247 \\
2009 & 1045682,11 & 645900,33 & 45394 & 3417783,31 & 5,66 & 2,45 & -3746015 & 11916807 & 29279099 \\
2010 & 1939836,89 & 962099,52 & 96684 & 5090952,14 & 7,38 & 2,68 & -3057496 & 21102642 & 54315433 \\
2011 & 643149,06 & 817796,96 & 3666 & 4697885,86 & 13,81 & 1,11 & -15669154 & 20298909 & 21223919 \\
2012 & 2129739,91 & 1164153,48 & 25571 & 6687552,58 & 10,14 & 3,30 & -1533873 & 27110836 & 70281417 \\
2013 & 2479065,21 & 1217363,15 & 53673 & 7098385,96 & 9,91 & 3,23 & -1412091 & 313808555 & 84288217 \\
2014 & 1846937,71 & 1020550,77 & 0 & 6037659,81 & 17,35 & 4,03 & -1093031 & 31138739 & 64642820 \\
2015 & 1941007,16 & 1057205,28 & 5876 & 6430728,64 & 9,33 & 3,12 & -4871591 & 27178823 & 71817265 \\
2016 & 2741752,28 & 1468362,68 & 7463 & 9169921,99 & 18,61 & 4,23 & -825801 & 48607750 & 106928339 \\
2017 & 2592516,40 & 1155606,76 & 0 & 7489187,78 & 9,69 & 3,18 & -2275978 & 33558354 & 108885689 \\
2018 & 2819463,04 & 1205755,57 & 3940 & 8177832,15 & 8,94 & 3,09 & -2308119 & 34303788 & 129695300 \\
\hline
\end{tabular}

(Source: author calculation relied on information of the entities' annual financial statements)

We can observe a progressive increase of the total net profit registered by the entities in the field of manufacturing basic pharmaceutical products in Romania, in the last 20 years. However, if we analyze the minimum value recorded by the 46 entities in each year taken into account, we notice that we have entities that record a loss each year from 1999 to 2018.

Table no 2: Descriptive statistics of turnover for entities in pharmaceutical fields in Romania in the period 1999-2018

\begin{tabular}{llllllllllll}
\hline Year & Mean & \multicolumn{7}{c}{ Standard Error Median } & \multicolumn{7}{c}{ Standard Deviation Kurtosis } & Skewness & Minimum & Maximum & Sum \\
\hline 1999 & 3667405,1 & 2446657,42 & 518343 & 10087827 & 13,31 & 3,58 & 0 & 40890612 & 62345886 \\
2000 & 5492976,8 & 3454992,26 & 577226 & 14658290,8 & 15,21 & 3,81 & 1692 & 62211167 & 98873582 \\
2001 & 7425259,9 & 4409561,19 & 763392 & 20207147,9 & 16,41 & 3,93 & 0 & 91106668 & 155930457 \\
2002 & 9701258,1 & 5478976,34 & 1016258 & 24502727,1 & 15,40 & 3,80 & 0 & 108235742 & 194025162 \\
2003 & 9912011,2 & 5808055,33 & 1358477 & 26615853,2 & 17,39 & 4,06 & 0 & 121495051 & 208152236 \\
2004 & 13090668 & 6695600,91 & 889072 & 32110973,9 & 10,49 & 3,20 & 0 & 136028514 & 301085366 \\
2005 & 13003325 & 7131831,06 & 591197 & 35659155,3 & 14,36 & 3,71 & 0 & 163497747 & 325083131 \\
2006 & 15780150 & 8696690,1 & 927641 & 44344592,5 & 12,33 & 3,53 & 0 & 195677945 & 410283900 \\
2007 & 18542407 & 9982220,64 & 761451 & 52820946,7 & 11,82 & 3,51 & 0 & 229415602 & 519187395 \\
2008 & 21048082 & 11520949,6 & 1177906 & 60963134,8 & 11,31 & 3,49 & 0 & 253892410 & 589346290 \\
2009 & 22032214 & 11567054,4 & 1193075 & 61207098,7 & 10,66 & 3,39 & 0 & 250467914 & 616901989 \\
2010 & 2521274 & 13283453,9 & 1275796 & 70289431,2 & 10,31 & 3,31 & 0 & 290645714 & 714595680
\end{tabular}


Lumen Proceedings 14 | International Conference IBMAGE 2020

\begin{tabular}{llllllllll}
2011 & 23285447 & 11780517,7 & 792568 & 67673921,7 & 11,72 & 3,52 & 0 & 281847455 & 768419756 \\
2012 & 24332916 & 12058057,1 & 1005023 & 69268264,5 & 12,01 & 3,53 & 0 & 304731950 & 802986221 \\
2013 & 25068622 & 12244890,8 & 662203 & 71399369,3 & 12,03 & 3,52 & 0 & 318625015 & 852333156 \\
2014 & 26319524 & 12654849,4 & 618201 & 74867098,6 & 12,04 & 3,54 & 0 & 320058303 & 921183344 \\
2015 & 26354851 & 12767289,1 & 377009 & 77660387,7 & 13,15 & 3,69 & 0 & 338174107 & 975129495 \\
2016 & 24677247 & 11861000,9 & 519991 & 74071926,6 & 14,11 & 3,81 & 0 & 334990734 & 962412622 \\
2017 & 24847753 & 11717542,7 & 449665 & 75938355,7 & 14,06 & 3,79 & -1540 & 345758646 & 1043605605 \\
2018 & 23835099 & 11424771 & 209286 & 77486566,9 & 15,32 & 3,96 & 0 & 365304988 & 1096414564 \\
\hline
\end{tabular}

(Source: author calculation relied on information of the entities' annual financial statements)

And in the case of turnover we are witnessing a progressive growth in the analyzed period. We can also observe the fact that we have entities that register a turnover equal to 0 every year taken into account from 19992018, except for the year 2000 and 2017.

For each year we determined the turnover, the gross / net profit, the own capitals, the total assets by summing up these indicators for each analyzed entity. Based on the total, we calculated the profitability indicators and subsequently represented graphically the evolution in their dynamics. In the table below we find the situation of financial indicators (net profit, turnover, total assets and equity) as well as ROA, return on capital-ROE, and return on sales -ROS) for the entities in the field of manufacture of basic pharmaceutical products in Romania, in the period 1999-2018:

Table no. 3: Statement of financial indicators and rates of return for entities in pharmaceutical fields in Romania in the period 1999-2018

\begin{tabular}{rrrrrrrr}
\hline Year & Net Profit & Turnover & $\begin{array}{l}\text { Total } \\
\text { assets }\end{array}$ & Equity & ROA & ROE & \multicolumn{1}{c}{ ROS } \\
\hline $\mathbf{1 9 9 9}$ & 5073791 & 62345886 & 70693984 & 39445653 & 7,18 & 12,86 & 9,83 \\
$\mathbf{2 0 0 0}$ & 7738297 & 98873582 & 122364418 & 68167643 & 6,32 & 11,35 & 9,61 \\
$\mathbf{2 0 0 1}$ & 19690103 & 155930457 & 205245921 & 103443745 & 9,59 & 19,03 & 15,13 \\
$\mathbf{2 0 0 2}$ & 18560097 & 194025162 & 290182663 & 132056364 & 6,4 & 14,05 & 11,82 \\
$\mathbf{2 0 0 3}$ & 22873947 & 208152236 & 358501175 & 175298080 & 6,38 & 13,05 & 13,57 \\
$\mathbf{2 0 0 4}$ & 23468803 & 301085366 & 428355562 & 200384761 & 5,48 & 11,71 & 10,1 \\
$\mathbf{2 0 0 5}$ & 30095716 & 325083131 & 471335315 & 232065761 & 6,39 & 12,97 & 11,08 \\
$\mathbf{2 0 0 6}$ & 54793557 & 410283900 & 572426335 & 292006957 & 9,57 & 18,76 & 15,58 \\
$\mathbf{2 0 0 7}$ & 34147798 & 519187395 & 729824262 & 360716084 & 4,68 & 9,47 & 7,79 \\
$\mathbf{2 0 0 8}$ & -8444247 & 589346290 & 869695858 & 389116645 & $-0,97$ & $-2,17$ & $-0,63$ \\
$\mathbf{2 0 0 9}$ & 29279099 & 616901989 & 921937119 & 386920971 & 3,18 & 7,57 & 5,95 \\
$\mathbf{2 0 1 0}$ & 54315433 & 714595680 & 965376472 & 500641135 & 5,63 & 10,85 & 9,36 \\
\hline
\end{tabular}


Lumen Proceedings 14 | International Conference IBMAGE 2020

\begin{tabular}{rrrrrrrr}
\hline $\mathbf{2 0 1 1}$ & 21223919 & 768419756 & 1077531943 & 529159211 & 1,97 & 4,01 & 4,94 \\
$\mathbf{2 0 1 2}$ & 70281417 & 802986221 & 1221565848 & 621409563 & 5,75 & 11,31 & 10,42 \\
$\mathbf{2 0 1 3}$ & 84288217 & 852333156 & 1260529628 & 656150432 & 6,69 & 12,85 & 11,39 \\
$\mathbf{2 0 1 4}$ & 64642820 & 921183344 & 1277064853 & 682578286 & 5,06 & 9,47 & 8,77 \\
$\mathbf{2 0 1 5}$ & 71817265 & 975129495 & 1379454990 & 741193899 & 5,21 & 9,69 & 8,74 \\
$\mathbf{2 0 1 6}$ & 106928339 & 962412622 & 1458547108 & 833740989 & 7,33 & 12,83 & 13,29 \\
$\mathbf{2 0 1 7}$ & 108885689 & 1043605605 & 1628589725 & 978729917 & 6,69 & 11,13 & 11,84 \\
$\mathbf{2 0 1 8}$ & 129695300 & 1096414564 & 1837821548 & 1057629222 & 7,06 & 12,26 & 13,22 \\
\hline
\end{tabular}

(Source: author calculation relied on information of the entities' annual financial statements)

The evolution in dynamics of the return on assets and the return on equity for the entities in the field of manufacture of basic pharmaceutical products in Romania for the period 1999-2018 is illustrated in the graph below:

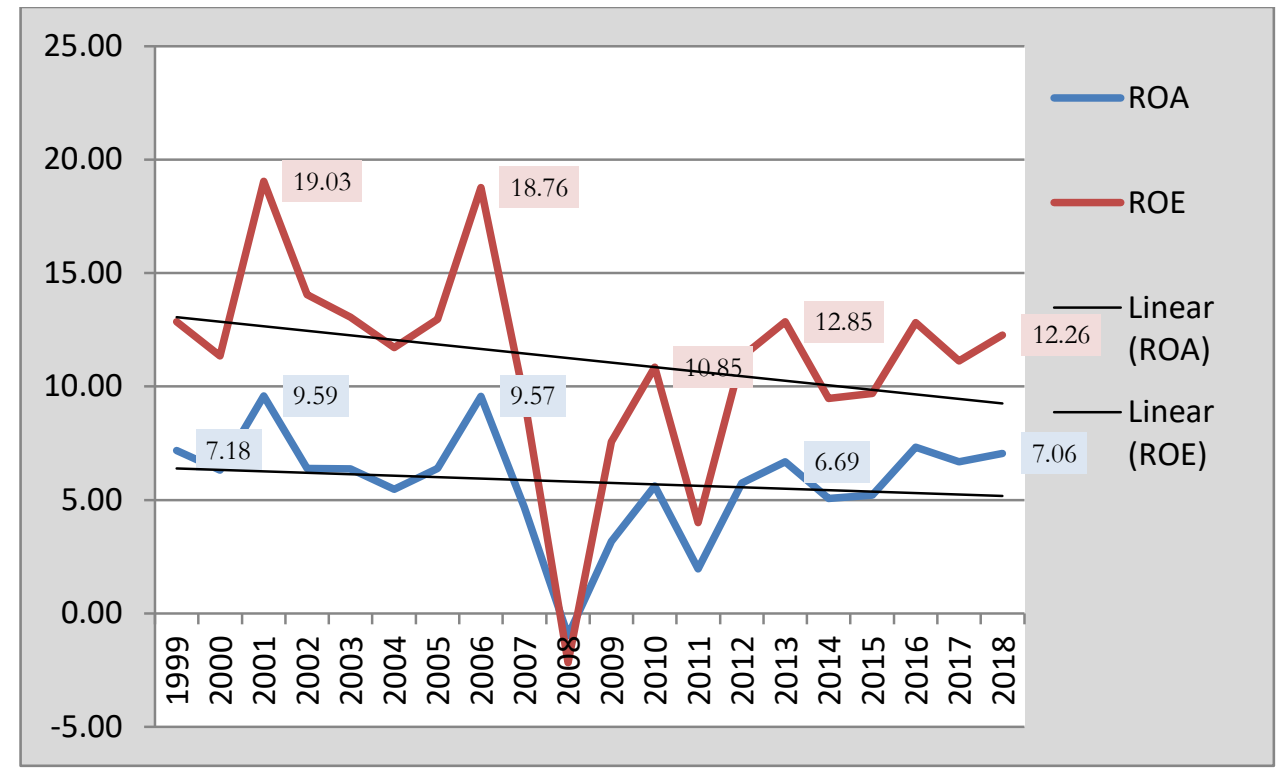

Graph no. 1. Evolution of ROA and ROE for pharmaceuticals entities in the period 1999-2018

(Source: author calculation relied on information of the entities' annual financial statements)

The evolution of the rate of return on assets is directly proportional to the evolution of profit, so that we can see in 2008 an unfavorable evolution of ROA (year in which the indicator registers a negative value) due to the loss of entities in the pharmaceutical industry due to financial crisis. If we take the entire analysis period, the trend of the rate of return on assets is 
slightly downward, and even if total assets have grown steadily, profit has managed to influence this fluctuating evolution of ROA. In 2001, 2006, 2010, 2013, 2016 we see a significant increase in economic profitability, in fact illustrating the efficiency of using assets for profit. We can notice in the chart above an evolution of the ROE similar to evolution of ROA, given its use as an indicator for calculating net profit. In 2001, the entities in the field of manufacturing of basic pharmaceutical products (CANE: 2110) recorded the highest value of the rate of return on capital, of $19.03 \%$, which translates into a gain of $19.03 \%$ on an investment of 100 lei capital. The financial return on capital has a relatively irregular evolution during the analysis period, on the whole registering a very slightly downward trend being associated with a lower efficiency of the financial activity in terms of capitalization.

The evolution in the dynamics of rate on sales is illustrated in the graph below:

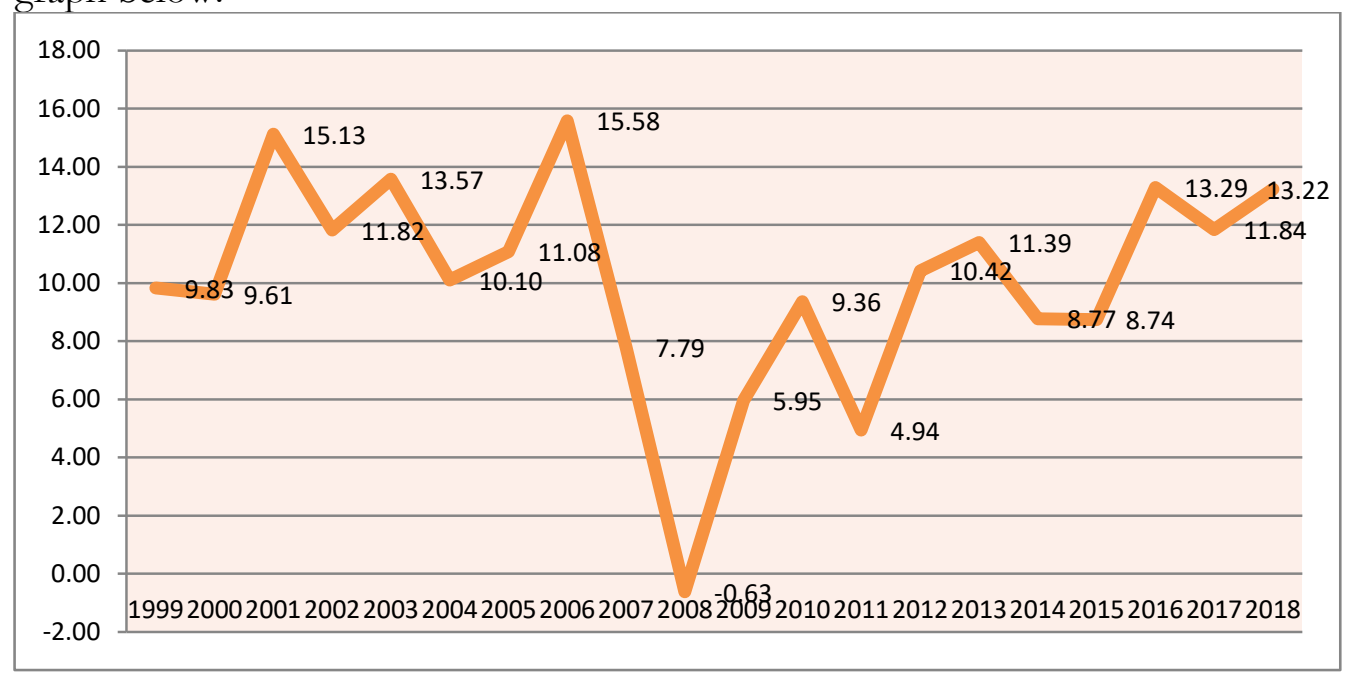

Graph no. 2. Evolution of ROS in pharmaceutical field in the period 1999-2018 (Source: author calculation relied on information of the entities' annual financial statements)

We can see in the chart above an alarming decrease in the rate of commercial profitability in 2008. Two years later, in 2009-2010, economic entities begin to recover commercially, but nevertheless in the period 20092018 they fail to return to the values recorded before the crisis. The maximum value of the rate is registered in 2006, which means that at a turnover of 100 lei the entity will register a profit of $15.58 \%$. 


\section{Discussions}

The pharmaceutical sector is very offering in terms of assessing financial performance. The assessment of performance and profitability must aim at both profitability (ability to make a profit, and solvency, liquidity and financial balance. In a future research we aim to analyze the liquidity and solvency of the Romanian pharmaceutical sector for the last 20 years.

\section{Conclusions}

The study of the financial performance of the economic entities in the pharmaceutical field in Romania is a necessary concern in the conditions of a progressive annual increase of the profitability of this sector. Statistics have shown that the pharmaceutical industry is one of the most competitive and dynamic in the sectors of activity on the market, which is why competition is very close. Barriers to entry in this market, as well as research and development costs are relatively high, so that they use mergers and acquisitions, mainly in the innovative area of industry, thus generating one of the most active economic segments, after the banking sector [20]. Following the analysis of profitability indicators (return on assets, capital, and sales) as part of activity of assessing the financial performance of economic entities operating in Romania in the pharmaceutical industry (manufacturing of basic pharmaceutical products - CAEN code 2110), the paper presents the most current concepts related to the performance assessment based on profitability indicators, as well as the description of the research interests of the pharmaceutical sector. We analyzed the profitability indicators for for a number of 46 entities in the pharmaceutical industry in Romania for a period of 20 years (1999-2018).

We are talking in this case about a turnover of 1.1 Billion lei (249.2 million euros), a number of employees of 3,098 employees, a profit of 135.2 million lei (30.7 million euros) - representing $0.12 \%$ of the net profit made in Romania [24]. The research results show that in the period 2008-2009, the financial crisis left a strong mark on the evolution of profitability in the pharmaceutical industry. However, during the 20 years we talk about a positive evolution, in the sense of increasing the profitability of this field, which justifies the increase in the consumption of pharmaceuticals products.

\section{References}

[1] Balteș N, Minculete (Piko) G. Current accounting reports - information source on assessing the financial performance of economic entities. Case study: 
pharmaceutical industry, CECCCAR Business Magazine, Business expertise and audit. 2017;2.

[2] Beranova M, Polak J. Changes in view of financial position and performance of a company at application of IFRS in the Czech Republic. Acta academica karviniensia. 2014;14(1):16-23. Available from: https://aak.slu.cz/pdfs/aak/2014/01/02.pdf

[3] Burja C. Economic-financial analysis: methodological aspects and practical applications. Cluj-Napoca: Casa Cărții de Știință Publishing House; 2009. pg. 290.

[4] Burja V. The analysis of the financial statements of companies. Alba Iulia: Aeternitas Publishing; 2010.

[5] Carp A, Mirea M. Profitability as a form of communication of the value of an entity that operates for profit. Romanian Statistical Review. 2017;6:184-191

[6] Carp D. Romanian pharmaceutical market, record business in 2018, 2018 [Internet]. Available from: https://www.dcnews.ro/pia-a-farmaceutica-dinromania-afacerirecord-in-2018 586158.html

[7] Căruntu C, Lăpăduși LM. Financial profitability rate. The impact of the rate of financial profitability on the development of the enterprise. Annals of Constantin Brâncuși University of Târgu Jiu, Economy Series. 2009;2:95-108.

[8] Căruntu C, Lăpăduși LM. Measures to increase the rates of return based on the diagnosis analysis on factors. Annals of the Constantin Brâncuşi University of Târgu Jiu, Economy Series. 2012;2:57-68.

[9] CECCAR. Case Study on Entity Performance Assessment (II). Business Expertise and Audit. 2020;4. Available from: https://www.ceccarbusinessmagazine.ro/studiu-de-caz-privind-evaluareaperformantei-entitatilor-ii-a5896/

[10] Deng Y, Zou S, You D. Financial performance evaluation of nuclear powerrelated enterprises from the perspective of sustainability, Environmental Science and Pollution Research. 2020;27(2):1-15. Available from: 10.1007/s11356-019-07545-1.

[11] Fenyves V, Nyul B, Dajnoki K, Bacs Z, Tomori G. Profitability of Pharmaceutical Companies in the Visegr $\tilde{A}_{j} \mathrm{~d}$ Countries. Montenegrin Journal of Economics, Economic Laboratory for Transition Research (ELIT). 2019;15(4):99-111.

[12] Ghic G, Grigorescu CJ. Economic-financial analysis: Individual study manual. Romania: Pro Universitaria Publishing House; 2012. pg. 65.

[13] Hada ID. Considerations Regarding the Assessment and Measurement of Financial Performance. Lumen Proceedings. 2020;13. 16th International International Conference NCOE 4.0 2020:115 -129.

[14] Issor Z. La performance de l'entreprise: un concept complexe aux multiples dimensions. Projectique. 2017;2(17):93-103. 
[15] Kolodziejka K. Pharmaceutical sector in the new reimbursement era. Management. 2012;16(1):203-215.

[16] Leahy AS. The Determinants Of Profitability In The Pharmaceutical Industry. American Journal of Health Sciences. 2012;3(1):37-42

[17] Mikulic M. Global Pharmaceutical Industry - Statistics \& Facts [nternet]. 2019. Available from: https://www.statista.com/topics/1764/globalpharmaceutical-industry $/$

[18] Nishanthini A, Nimalathasan B. Determinants of Profitability: A Case Study of Listed Manufacturing Companies in Sri Lanka. Journal of Management. 2013;VIII(1):42-50.

[19] Paliu-Popa L, Cosneanu L. Profit and loss account in the international context. Annals of the Constantin Brâncuși University of Târgu Jiu, Economy Series. 2011;2:18-25.

[20] Rotărescu AM. Biofarm financial performance analysis. ABC LUMII FINANCIARE working papers collection. 2017;5:211-230.

[21] Stănică FA, Străchinaru AI, Ilie V. Influences on the profitability of the pharmaceutical industry in Romania. Theoretical and Applied Economics, Asociatia Generala a Economistilor din Romania - AGER. 2015;0(Special I):97-105.

[22] Vasilescu L. Evaluation of the company's performance based on financial indicators. Annals of Constantin Brâncuși University of Târgu Jiu, Economics Series. 2011;3:159-166.

[23] Vesa L. Financial Performance - Turning Point for the Economic Entity. ABC Financial World Working Paper Collection. 2018;7:182-191.

[24] Top Firme [Internet]. Available from: www.topfirme.com

[25] Ministerul Finanțelor Publice [Internet]. Available from: www.mfinante.ro 